\title{
MINERALS AND SEDIMENTARY CHARACTERISTICS OF QUATERNARY SEDIMENTS OF DIFFERENT REGIONS IN SOUTHERN IRAQ
}

\author{
${ }^{1}$ Layal F. Al-Kaaby ${ }^{*}$ and ${ }^{2}$ Badir N. Albadran \\ ${ }^{1}$ Department of Science and Technology of Basra, Ministry of Science and Technology \\ ${ }^{2}$ Department of Geology, College of Science, University of Basrah \\ *Email: 1fsgeo@yahoo.com
}

Received: 2 June 2019; accepted: 3 September 2019

\begin{abstract}
This study tries to evaluate the sediments of Quaternary deposits with a depth from 8 to 24 meters, and determine the lights and heavy minerals with their origin. Three boreholes; Basrah, Thi-Qar and Missan, were selected, based on the grain size analysis of samples, three types of sediment were identified: silt, sandy silt, and silty sand. The statistical size parameters were applied to determine the energy and sedimentation environment, showed that the sediments of the study area were deposited in low-energy conditions. The sorting values ranged from poorly to very poorly, while the skewness ranged from strongly fine to near symmetrical skewed and kurtosis values ranged from platy to leptokurtic. The results of heavy minerals analysis proved the very low values comparative with light ones; Opaque was predominant in all study sites, accounting for about $50 \%$ of the heavy minerals and divided to mica minerals and Chlorite, Pyroxene, Amphibole, Zircon, Epidote, and Garnet, while Kyanite, Tourmaline and Staurolite. The light minerals are dominated by carbonate and quartz with few amounts of chert, evaporates, Feldspar, rock fragments and light muscovite. The difference in the values and diversity of heavy minerals in the study area indicates the multiple sources contributing to the deposits of the Mesopotamia Plain. The sources are limited between the rivers of Tigris, Euphrates and Shatt Al-Arab and the dust-fallouts, as well as the nearest formations and the Arabian shield.
\end{abstract}

Keywords: Quaternary; Mineral; Mesopotamia; Formation; Arabian Shield

\section{INTRODUCTION}

The Middle East comprises one of the most important geological sites, whereas this status gained from historical importance, especially in the Quaternary Period (1.65 M. Y). When many civilizations habitat this area over the years as Sumerian, Assyrian, Babylonian and Islamic 
civilizations to the present day, as well as the marshes which are considered to be one of the largest and most important wetlands in the Middle East even dried during 1991-2003. Quaternary deposits are the main constituent of the Mesopotamian sediment. The origin and formation of these sediments witnessed many scenarios due to the overlap between the sediments of the Tigris, Euphrates Rivers, and marine. The Mesopotamia Plain has undergone many studies, like a Abdullah (1982), Al-Sakini (1993), Al-Jumaily (1994), Al-Azzawi (1996), Al-Jibouri (1997), Al-Baidhany et al. (2002), Al-Hamad et al. (2015), Al-Hawi et al. (2017), Al-Malkei et al. (2017), and Pournelle et al. (2019). The study area is a part of the Mesopotamia Basin, which represents a major subsidence basin that began from the middle ages to the recent (Buday, 1980). This Basin is a mobile structural zone with many folds, faults and salt structures (Fouad, 2010; Fouad and Sissakian, 2011), it lies within the Unstable Shelf of the Arabian Plate (Buday and Jassim, 1987). For Jassim and Goff (2006), the Mesopotamian Zone is a stable shelf within the Arabian Plate. The Mesopotamia Plain is a sedimentary unit and wide lowland with clear physiographic boundaries; it is bordered by the Low Folded Zone from the northern and eastern sides, the Western Desert and Al-Jazira Area from the western side, and from the south to the Arabian Gulf (Yacoub, 2011a). Although the Mesopotamia plain has a gentle slope and low-level terrain, it did not prevent the presence of different geomorphological features (Yacoub et al., 1981). The Mesopotamian basin contains Quaternary sediments and is surrounded by the Tertiary sediments (Yacoub, 2011b), the thickness of these sediments is about $120 \mathrm{~m}$ (Bsho, 2004), that is revealed in the eastern and SE parts of Amara City, It belongs to Mukdadiya and Bai Hassan formations (Barwary, 1993). The sediments of Holocene are characterized by different environments, such as the fluvial, lacustrine, estuaries, and Aeolian environments, and others resulting from human activity and distributed in the Mesopotamia Plain (Yacoub, 2011b). Aqrawi (1995) explained that the deposition of this period was influenced by several factors, namely sedimentation rate, sea-level fluctuation, and neotectonic activities, and the thickness of these sediments range between 15-20 m. The source of these sediments is coming from the mountains of Taurus and Zagros and the drainage of the Tigris, Euphrates and Shatt Al-Arab rivers. This study is an attempt to predict the origin and provenance of these sediments through studying the heavy and light minerals.

\section{MATERIALS AND METHODS}

The study area includes the lower part of Mesopotamian basin, which represents the triangle between Basrah, Thi-Qar and Missan, specifically located between Latitude $32^{\circ} 30^{\prime} 0^{\prime}-30^{\circ} 0^{\prime} 0^{\prime \prime} \mathrm{N}$ and Longitude $45^{\circ} 30^{\prime} 0^{\prime \prime}-48^{\circ} 0^{\prime} 0^{\prime \prime}$ E (Fig. 1). Fieldwork and samples were executed in cooperation with many private and public laboratories to provide samples for the study area, due to the high 
cost of drilling. Three boreholes (Bh) were secured in the study area from these labs, one borehole in Emam Reidha quarter, Basrah (BR), and one in Ebtera, Missan (MI), while the samples of ThiQar were collected from the irrigation channels in Awadiyat (TN) (Table 1). The descriptions of these boreholes were mentioned in figures (2, 3, and 4). Samples were analyzed to determine the percentage of sand, silt and clay by the Master Sizer (Model UM 2000) in the Geology Department, University of Basrah. The heavy and light minerals were separated and identified in the Department of Geology, College of Science, University of Baghdad. The fine sand of size 3 and 4 phi was separated by a heavy liquid (bromoform) with a specific weight of 2.89 . The procedure of separating heavy and light minerals is done according to Müller (1967), Griffiths (1967), Carver (1971) and Tucker (1985). These minerals were identified using binocular and a polarized microscope.

Table 1: Source and location of boreholes in the study area

\begin{tabular}{|l|l|l|l|l|l|}
\hline $\begin{array}{l}\text { Bh. } \\
\text { Symbol }\end{array}$ & $\begin{array}{l}\text { Depth } \\
(\mathrm{m})\end{array}$ & $\begin{array}{l}\text { Graphical } \\
\text { location }\end{array}$ & $\begin{array}{l}\text { Latitude } \\
\mathrm{N}\end{array}$ & $\begin{array}{l}\text { Longitude } \\
\text { E }\end{array}$ & Source \\
\hline BR & 24 & $\begin{array}{l}\text { Basrah/Emam } \\
\text { Reidha quarter }\end{array}$ & $\begin{array}{l}30^{\circ} 31^{\prime} \\
42.7^{\prime \prime}\end{array}$ & $47^{\circ} 48^{\prime} 1.1^{\prime \prime}$ & $\begin{array}{l}\text { Engineering College lab/ } \\
\text { University of Basrah }\end{array}$ \\
\hline TN & 8 & $\begin{array}{l}\text { Thi } \\
\text { Qar/Awadiyat }\end{array}$ & $\begin{array}{l}31^{\circ} 24^{\prime} \\
18.29^{\prime \prime}\end{array}$ & $\begin{array}{l}46^{\circ} 33^{\prime} \\
43.65^{\prime \prime}\end{array}$ & Field work \\
\hline MI & 19 & Missan/ Ebtera & $31^{\circ} 51^{\prime} 4.6^{\prime \prime}$ & $\begin{array}{l}46^{\circ} 22^{\prime} \\
35.3^{\prime \prime}\end{array}$ & $\begin{array}{l}\text { General commission of ground } \\
\text { water/Missan }\end{array}$ \\
\hline
\end{tabular}

\section{RESULTS}

According to the classification of Folk (1974), the results of the grain size analysis in Basrah showed two types of sediments: silt, and sandy silt, while in Thi-Qar, three types were recorded, sandy silt, silty sand, and silt. In Missan there were two types, sandy silt, and silty sand, and the statistical size parameters are present in Table (2). The heavy and light minerals with their average are presented in tables $(3,4$, and 5). Plates (1-4) show the heavy and light minerals present in the study area.

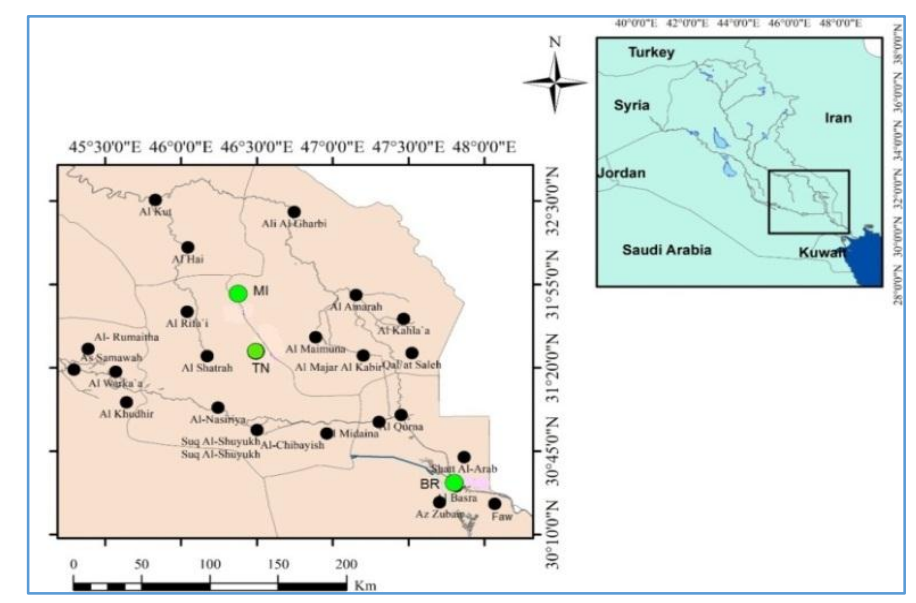

Fig. 1: Locations of the Boreholes (Rounded green circles are the boreholes) 
Table 2: Grain size analysis and statistical size parameters in the study area

\begin{tabular}{|c|c|c|c|c|c|c|c|c|c|c|c|}
\hline 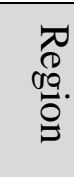 & 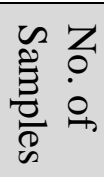 & 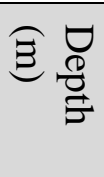 & 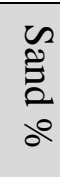 & $\underset{\partial}{\stackrel{\varrho}{\rightleftarrows}}$ & $\begin{array}{l}\stackrel{2}{2} \\
0 \\
0\end{array}$ & $\begin{array}{l}3 \\
8 \\
\stackrel{0}{0}\end{array}$ & $\begin{array}{l}3 \\
\stackrel{2}{0} \\
\stackrel{0}{0}\end{array}$ & 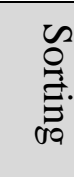 & 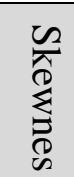 & $\begin{array}{l}\text { त्र } \\
\vdots \\
0 \\
0 \\
\omega\end{array}$ & $\begin{array}{l}\vec{\Theta} \\
\stackrel{x}{\Xi} \\
\stackrel{0}{0}\end{array}$ \\
\hline \multirow{8}{*}{ 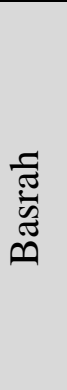 } & BR7 & 6 & 6 & 79 & 15 & 6.4 & 6.4 & 1.5 & 0.04 & 0.86 & Silt \\
\hline & BR7 & 6 & 6 & 79 & 15 & 6.4 & 6.4 & 1.5 & 0.04 & 0.86 & Silt \\
\hline & BR6 & 11 & 5 & 79 & 16 & 6.4 & 6.4 & 1.5 & 0.04 & 0.86 & Silt \\
\hline & BR5 & 14 & 5 & 80 & 15 & 6.5 & 6.4 & 1.53 & 0.04 & 0.88 & Silt \\
\hline & BR4 & 17 & 33 & 56 & 11 & 4.9 & 5.7 & 2.85 & -0.3 & 0.77 & Sand \\
\hline & BR3 & 20 & 22 & 57 & 21 & 5.5 & 6.4 & 3 & -0.4 & 1.15 & Sand \\
\hline & BR2 & 22 & 19 & 74 & 7 & 5.5 & 5.5 & 1.83 & - & 1.36 & Sand \\
\hline & BR1 & 24 & 23 & 67 & 10 & 5.6 & 5.5 & 2.02 & 0.80 & 0.81 & Sand \\
\hline \multirow{9}{*}{ 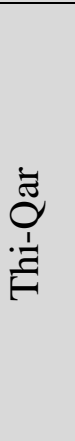 } & TN1 & 0.5 & 50 & 47 & 3 & 4.4 & 3.9 & 1.80 & 0.39 & 0.80 & Silty \\
\hline & TN2 & 1 & 70 & 28 & 2 & 3.5 & 3.2 & 1.6 & 0.20 & 1.0 & Silty \\
\hline & TN3 & 2 & 40 & 58 & 2 & 3.8 & 3.4 & 1.72 & 0.36 & 1.04 & Sand \\
\hline & TN4 & 3 & 76 & 23 & 1 & 3.4 & 3.3 & 1.55 & 0.56 & 1.31 & Silty \\
\hline & TN5 & 4 & 44 & 53 & 3 & 4.5 & 4.4 & 1.91 & 0.07 & 0.8 & Sand \\
\hline & TN6 & 5 & 10 & 79 & 11 & 5.8 & 5.8 & 1.46 & 0.04 & 1.13 & Sand \\
\hline & TN7 & 6 & 42 & 52 & 6 & 4.8 & 4.7 & 2.0 & 0.08 & 0.86 & Sand \\
\hline & TN8 & 7 & 9 & 83 & 8 & 5.8 & 5.6 & 1.42 & 0.17 & 1.25 & Silt \\
\hline & TN9 & 8 & 83 & 16 & 1 & 3.4 & 2.8 & 1.38 & 0.60 & 1.75 & Silty \\
\hline \multirow{19}{*}{ 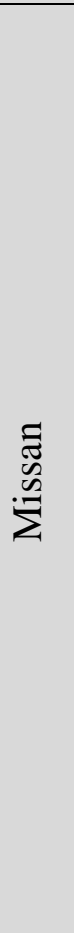 } & MI19 & 1 & 32 & 62 & 6 & 5 & 5.1 & 2.16 & - & 1.0 & Sand \\
\hline & MI18 & 2 & 34 & 60 & 6 & 5.3 & 5.3 & 1.07 & - & 1.5 & Sand \\
\hline & MI17 & 3 & 58 & 38 & 4 & 4.1 & 4.1 & 2.02 & 0.1 & 0.7 & Silty \\
\hline & MI16 & 4 & 47 & 47 & 6 & 6.7 & 4.5 & 2.08 & 0.02 & 0.81 & Sand \\
\hline & MI15 & 5 & 53 & 43 & 4 & 4.03 & 3.7 & 2.1 & 0.24 & 0.76 & Silty \\
\hline & MI14 & 6 & 60 & 38 & 2 & 3.9 & 3.5 & 2.1 & 0.26 & 0.84 & Silty \\
\hline & MI13 & 7 & 62 & 35 & 3 & 3.8 & 3.3 & 2.2 & 0.28 & 0.93 & Silty \\
\hline & MI12 & 8 & 30 & 64 & 6 & 5.3 & 5.3 & 2 & - & 1.12 & Sand \\
\hline & MI11 & 9 & 55 & 41 & 4 & 4.3 & 4.2 & 2.03 & 0.11 & 1.15 & Silty \\
\hline & MI10 & 10 & 35 & 60 & 5 & 4.9 & 4.9 & 2.01 & 0.01 & 1.10 & Sand \\
\hline & MI9 & 11 & 57 & 40 & 3 & 4.2 & 4.2 & 2.05 & 0.05 & 0.80 & Silty \\
\hline & MI8 & 12 & 50 & 46 & 4 & 4.3 & 4.0 & 2.02 & 0.12 & 0.80 & Silty \\
\hline & MI7 & 13 & 49 & 46 & 5 & 4.6 & 4.2 & 2.2 & 0.23 & 0.81 & Sand \\
\hline & MI6 & 14 & 51 & 46 & 3 & 4.6 & 4.3 & 2.1 & 0.16 & 0.80 & Silty \\
\hline & MI5 & 15 & 43 & 52 & 5 & 4.6 & 4.5 & 2 & 0.1 & 0.80 & Sand \\
\hline & MI4 & 16 & 40 & 53 & 7 & 4.7 & 4.5 & 2.04 & 0.13 & 0.86 & Sand \\
\hline & MI3 & 17 & 50 & 45 & 5 & 4.4 & 4.1 & 1.9 & 0.22 & 0.80 & Silty \\
\hline & MI2 & 18 & 43 & 52 & 5 & 4.7 & 4.5 & 1.9 & 0.16 & 0.77 & Sand \\
\hline & MI1 & 19 & 60 & 36 & 4 & 4.1 & 3.5 & 1.9 & 0.43 & 0.83 & Silty \\
\hline
\end{tabular}


Table 3: Percentage of heavy and light minerals of the study area

\begin{tabular}{|c|c|c|c|c|}
\hline Region & Sample Number & Depth & $\begin{array}{c}\text { Percentage of Light } \\
\text { Minerals }\end{array}$ & $\begin{array}{c}\text { Percentage of Heavy } \\
\text { Minerals }\end{array}$ \\
\hline & & (m) & $(\%)$ & $(\%)$ \\
\hline \multirow{7}{*}{ 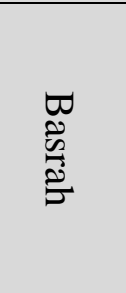 } & BR1 & 6 & 96.4 & 3.6 \\
\hline & BR2 & 11 & 96.0 & 4.0 \\
\hline & BR3 & 14 & 96.2 & 3.8 \\
\hline & BR4 & 17 & 93.8 & 6.2 \\
\hline & BR5 & 20 & 95.2 & 4.8 \\
\hline & BR6 & 22 & 95.4 & 4.6 \\
\hline & BR7 & 24 & 95.4 & 4.6 \\
\hline \multirow{5}{*}{ 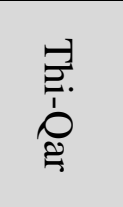 } & $\mathrm{TN} 1$ & 0.5 & 92.4 & 7.6 \\
\hline & TN3 & 2 & 96.4 & 3.6 \\
\hline & TN5 & 4 & 92.2 & 7.8 \\
\hline & TN7 & 6 & 90.2 & 9.8 \\
\hline & TN9 & 8 & 97.2 & 3.8 \\
\hline \multirow{10}{*}{ 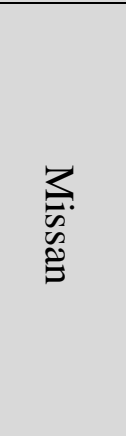 } & MI1 & 1 & 95.8 & 4.2 \\
\hline & MI2 & 2 & 95.6 & 4.4 \\
\hline & MI4 & 4 & 90.6 & 9.4 \\
\hline & MI6 & 6 & 92.0 & 8.0 \\
\hline & MI8 & 8 & 91.4 & 8.6 \\
\hline & MI10 & 10 & 96.0 & 4.0 \\
\hline & MI12 & 12 & 92.2 & 7.8 \\
\hline & MI14 & 14 & 91.6 & 8.4 \\
\hline & MI16 & 16 & 94.6 & 5.4 \\
\hline & MI18 & 18 & 93.4 & 6.6 \\
\hline
\end{tabular}


Table 4: Range and average of heavy minerals in the study area

\begin{tabular}{|l|c|c|c|c|c|c|}
\hline \multirow{2}{*}{ Heavy Minerals } & \multicolumn{2}{|c|}{ Basrah (BR) } & \multicolumn{2}{c|}{ Thi-Qar (TN) } & \multicolumn{2}{c|}{ Missan (MI) } \\
\cline { 2 - 7 } & Range & Average & Range & Average & Range & Average \\
\hline Opaques & $40.8-46.7$ & 44.34 & $43.2-49.2$ & 46.16 & $42.3-50.7$ & 46.84 \\
\hline Chlorite & $6.5-9.2$ & 7.81 & $9.1-10.4$ & 9.72 & $8-11.2$ & 9.03 \\
\hline Garnet & $2.2-4.2$ & 3.62 & $4.4-6.4$ & 5.2 & $3.2-6.4$ & 5.06 \\
\hline Zircon & $4.8-6.1$ & 5.54 & $4.5-5.4$ & 5.04 & $3.8-6.5$ & 5.16 \\
\hline OrthoPyroxene & $2.3-4.9$ & 3.11 & $2.3-3.9$ & 2.98 & $1.6-3.4$ & 2.81 \\
\hline ClinoPyroxene & $3.5-5.2$ & 4.21 & $3-4.6$ & 3.74 & $2.8-5.7$ & 4.2 \\
\hline Amphibole & $4.1-5.3$ & 4.71 & $3.1-6.1$ & 5.14 & $5-7.2$ & 5.98 \\
\hline Epidote & $4.2-6.3$ & 5.27 & $4.7-6.4$ & 5.96 & $5.1-7.1$ & 5.86 \\
\hline Biotite & $4.7-6.4$ & 5.37 & $4.3-4.7$ & 4.48 & $2.2-6.5$ & 3.36 \\
\hline Muscovite & $5.7-6.8$ & 6.1 & $4.3-7.2$ & 5.64 & $2.5-7.6$ & 4.53 \\
\hline Tourmaline & $3.1-4.1$ & 3.53 & $1.9-4.1$ & 2.6 & $1.3-4.3$ & 2.58 \\
\hline Staurolite & $0.7-2.7$ & 2.04 & $0.6-0.6$ & 0.6 & $0.3-2.6$ & 1.83 \\
\hline Kyanite & $2.1-2.6$ & 2.36 & $1.3-2.7$ & 2.12 & $1-2.3$ & 1.59 \\
\hline Others & $1.4-2.5$ & 1.96 & $0.5-1.7$ & 1.1 & $0.5-1.8$ & 1.35 \\
\hline
\end{tabular}

Table 5: Range and average of light minerals in the study area

\begin{tabular}{|l|c|c|c|c|c|c|}
\hline \multirow{2}{*}{ Light components } & \multicolumn{2}{|c|}{ Basrah } & \multicolumn{2}{c|}{ Thi-Qar (TN) } & \multicolumn{2}{c|}{ Missan (MI) } \\
\cline { 2 - 7 } & Range & Average & Range & Average & Range & Average \\
\hline Monocrystalline Quartz & $18.3-23$ & 21.7 & $17.6-20.6$ & 18.92 & $14.1-22.5$ & 19.18 \\
\hline Polycrystalline Quartz & $2.8-5.7$ & 3.93 & $2.5-4.7$ & 3.46 & $2.1-6.6$ & 3.78 \\
\hline Alkali Feldspar Orthoclase & $2.3-3.5$ & 2.64 & $2.6-3.9$ & 3.06 & $2-3.7$ & 2.86 \\
\hline Alkali Feldspar Microcline & $1.8-2.9$ & 2.46 & $1.6-3.3$ & 2.24 & $0.7-2.8$ & 1.76 \\
\hline Plagioclase Feldspar & $2.2-3.8$ & 3.07 & $2.2-4.7$ & 3.72 & $2.3-4.7$ & 3.76 \\
\hline Carbonate Minerals & $21.7-32.5$ & 27.3 & $29.8-33.8$ & 32.12 & $24.8-34.5$ & 31.61 \\
\hline Chert Rock Fragments & $8.2-12.5$ & 10.8 & $6.5-11.2$ & 9.14 & $5.3-10$ & 8.25 \\
\hline Igneous Rock Fragments & $2.8-4.3$ & 3.71 & $2-3.9$ & 3.1 & $2.1-5.6$ & 3.17 \\
\hline Metamorphic Rock Fragments & $1.6-4.5$ & 3.47 & $2.3-3.4$ & 2.9 & $1.6-3.8$ & 3.07 \\
\hline Mudstone Rock Fragments & $3.4-5.7$ & 4.31 & $2.6-3.9$ & 3.42 & $3-5.8$ & 4.06 \\
\hline Evaporates & $6.8-10.3$ & 8.08 & $6.6-9.1$ & 7.62 & $6.9-10.8$ & 8.59 \\
\hline Coated Clay & $2.0-3.1$ & 2.43 & $1.7-3.8$ & 2.62 & $2.5-3.3$ & 3 \\
\hline Light Muscovite & $3.3-4.5$ & 4.16 & $4.5-7.4$ & 5.52 & $2.7-6.9$ & 5 \\
\hline Others & $1.5-2.5$ & 1.93 & $1.6-2.8$ & 2.16 & $1.4-2.7$ & 1.91 \\
\hline
\end{tabular}




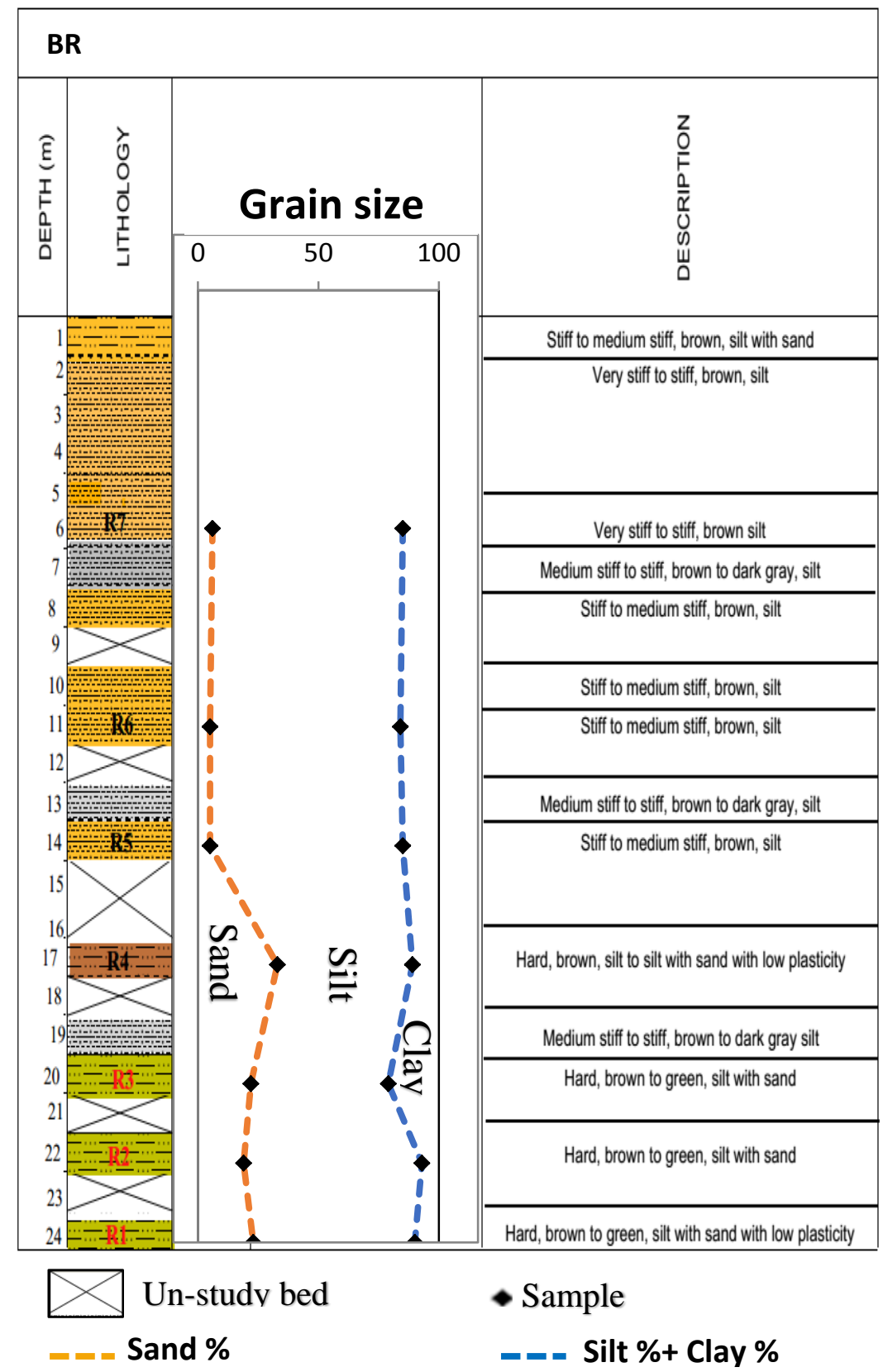

Fig. 2: Lithology of Emam Reidha quarter (BR), Basrah region 


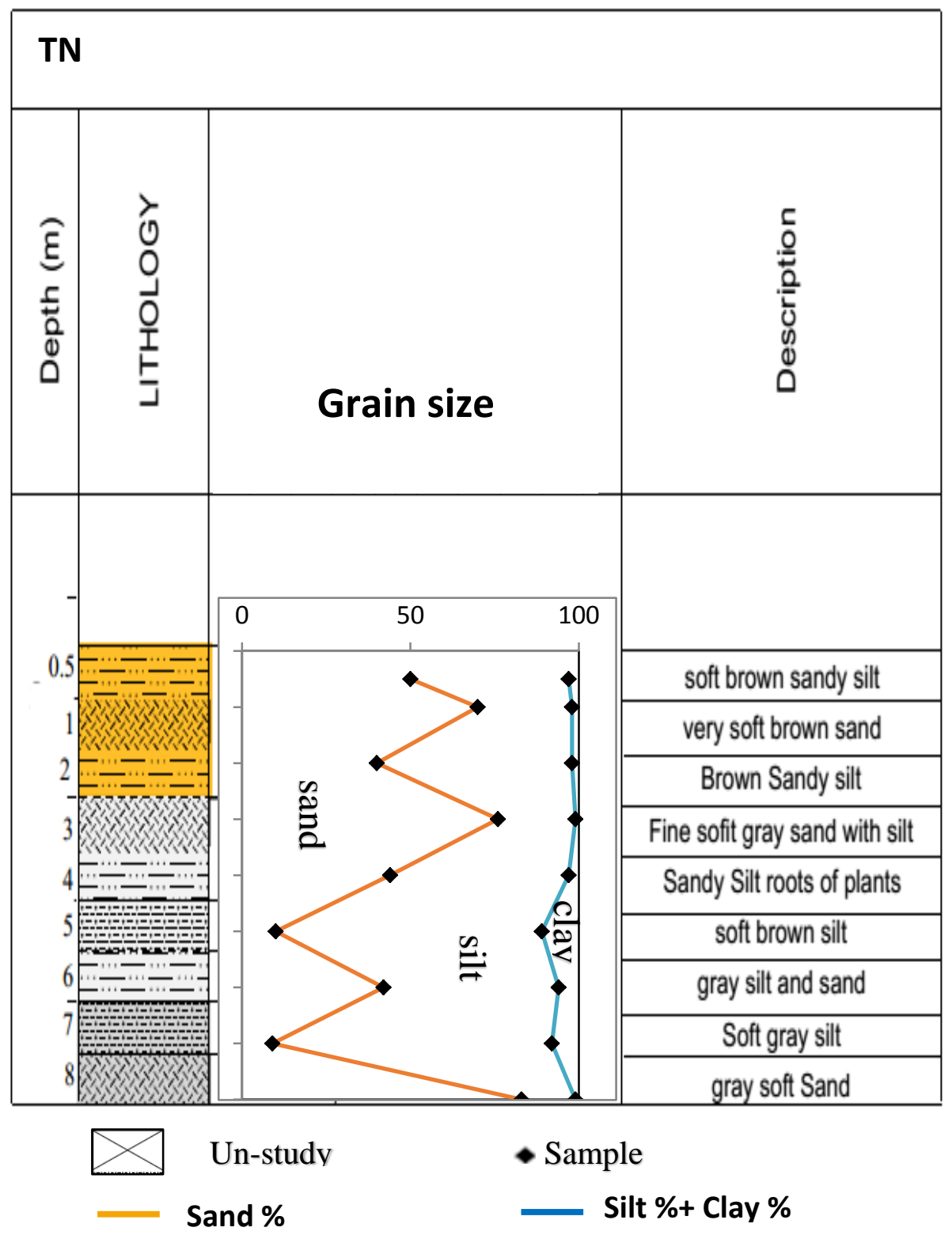

Fig. 3: Lithology of Thi-Qar region 


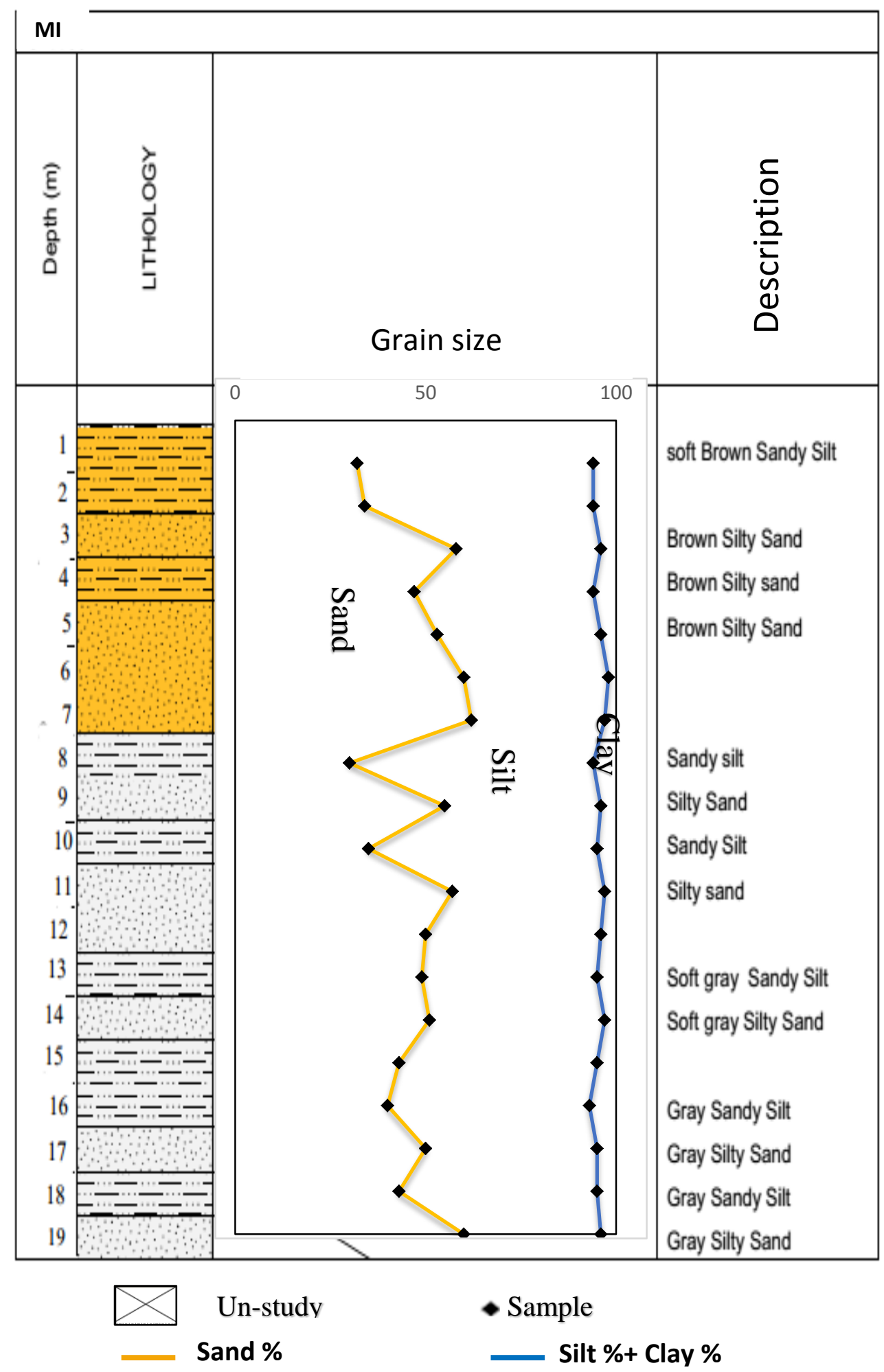

Fig. 4: Lithology of Ebtera (MI), Missan region 


\section{DISCUSSION}

\section{Sedimentological Study}

Grain size analysis shows that the sediments of the Basrah region are silty sand and sandy silt (Fig. 2) which are generally characterized by finning upward. While Thi-Qar region included three types of sediments, silty sand, sandy silt and silt (Fig. 3). The Missan regions, two types of sediments were recorded, silty sand and sandy silt (Fig.4). The texture of the two regions Missan and Thi-Qar are similar, possibly due to the distance between them and or that they could belong to the same sedimentary environment.

In general, the results recorded in the present study of granular size consisting of silts and very fine sand could relate to weak energy, where the coarse sediments of the Tigris and Euphrates Rivers are deposited when entering the marshes, and the finest sediments (fine silt and clay) reach to the Shatt Al-Arab River. The addition also comes from the erosion of the river bank (Albadran, 1987). This thought is also explained by an increase in sand and silt ratios in the northern part of the study area. The increase of silt sediment type in the study area could refer to the fluvial environments. The values of the statistical size parameters show that the sorting ranges from very poor to poor sorting in the three regions this can be attributed to the low sedimentation energy and the sedimentary environments in the three regions with a similar condition which could belong to the lakes and low depressions of the area. This makes certain from the mean size values wherein Basrah sediments ranged between 4.9 and 6.5 which show the fine of the granular size, in Missan, the average values ranged from 3.8- to 6.7, and in Thi Qar, there is a rapprochement of Missan, as well as an intermediate situation between Missan and Basrah. The diversity in the values of Skewness and Kurtosis values in the study area were close (Table 2), their values indicate that the size of the sediment is fine to very fine and this could reflect the low energy of the sedimentary conditions.

\section{Mineralogical Study}

The presence of heavy minerals in the sedimentary rocks and detrital sediments is varied, not necessarily that these minerals are connected with each other, but the method of separation and isolating them is determined as a group, these minerals reflect the parent's rocks after being stripped and weathered (Jasim, 2009). Heavy minerals are used to identify the source rocks (Boggs, 2006), as well as the identification of sedimentary environments (Kasper-Zubillage et al., 2008). Al-Bassam (1999) pointed out that the study of the heavy minerals in ancient and recent sediments is important to 
determine the degree of maturation of the sediment and its relation to the climate as well as the transport distance and sedimentation cycles.

The percentage of heavy to light minerals indicates that the samples in the three regions have varying proportions in some beds and are converging in the others this could belong to the different conditions of the supplied source. The percentage of heavy minerals in the Basrah region is very close in most of the depth but varies from depth 17 to $22 \mathrm{~m}$ (Fig.6) and the sedimentation environment in this bed could be different. This depth could be the top of the Dibdibba Formation. While in the Thi-Qar region the percentage of heavy minerals is high in depths $(0.5 ; 4 ; 6$ and $8 \mathrm{~m})$ and low in depth $(2 \mathrm{~m})$ (Fig. 7). This is also observed in Missan (Fig. 8). The difference in the percentage of minerals in the depths is attributed to several factors; including climatic changes that affect the weathering processes in the source rock region (Folk, 1974 and Pettijohn, 1975), as well as the river meanders and grain size of sediments affect the concentrations of heavy minerals. The difference in heavy minerals with depth, some of them are increasing and others are decreasing (Figs. 6, 7, and 8), this could explain the interference between the sedimentary environments; from the river to marsh or under the influence of dust-fallouts as well as the formation of some minerals in the same environment as a result of the diagenesis and alterations.

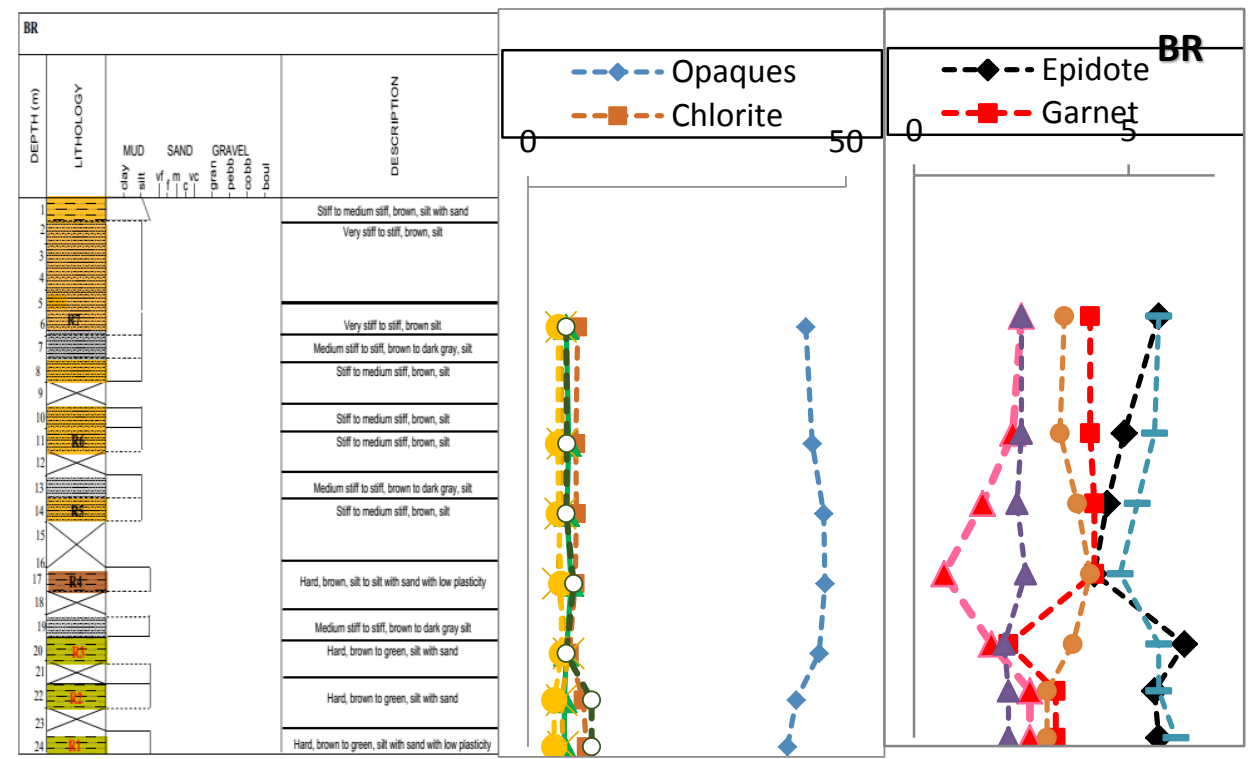

Fig. 6: Vertical variations in the percentage of the heavy minerals of Basrah region 


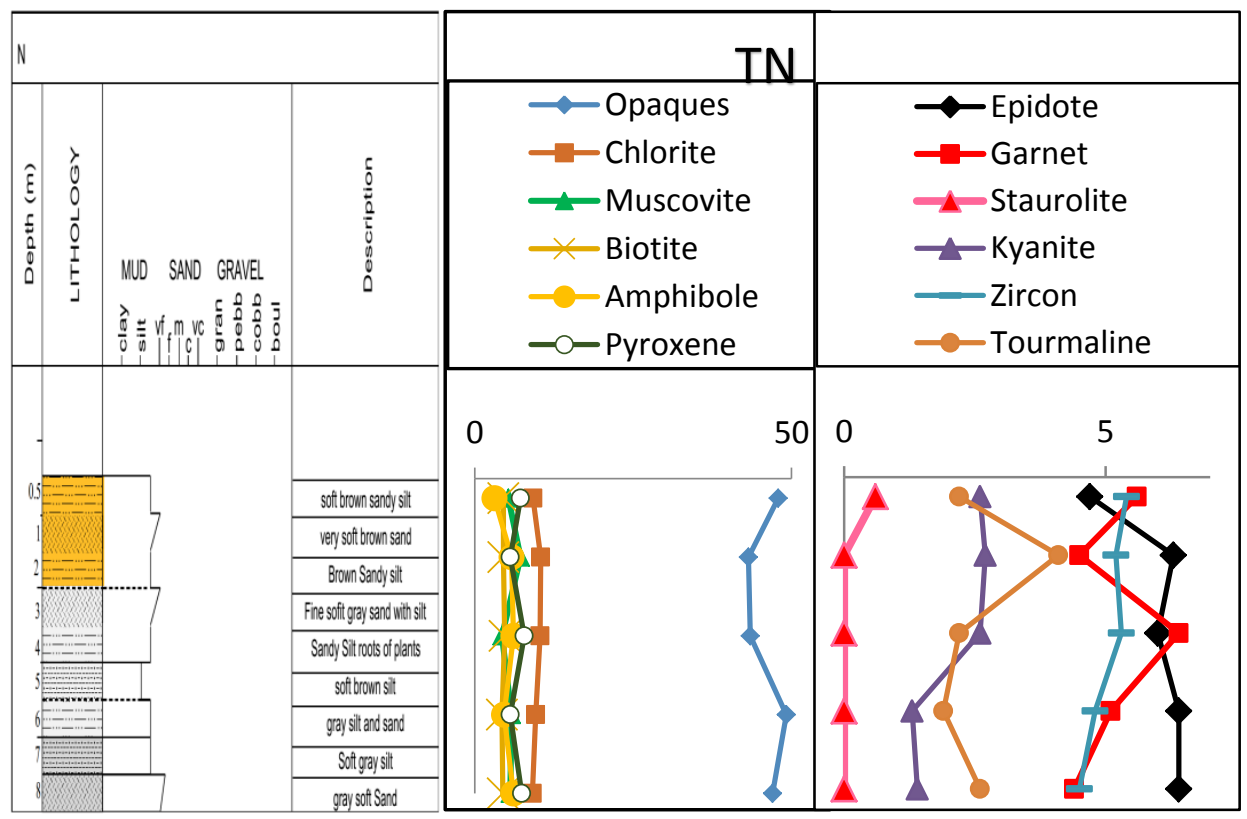

Fig. 7: Vertical variations in the percentage of the heavy minerals of Thi-Qar region

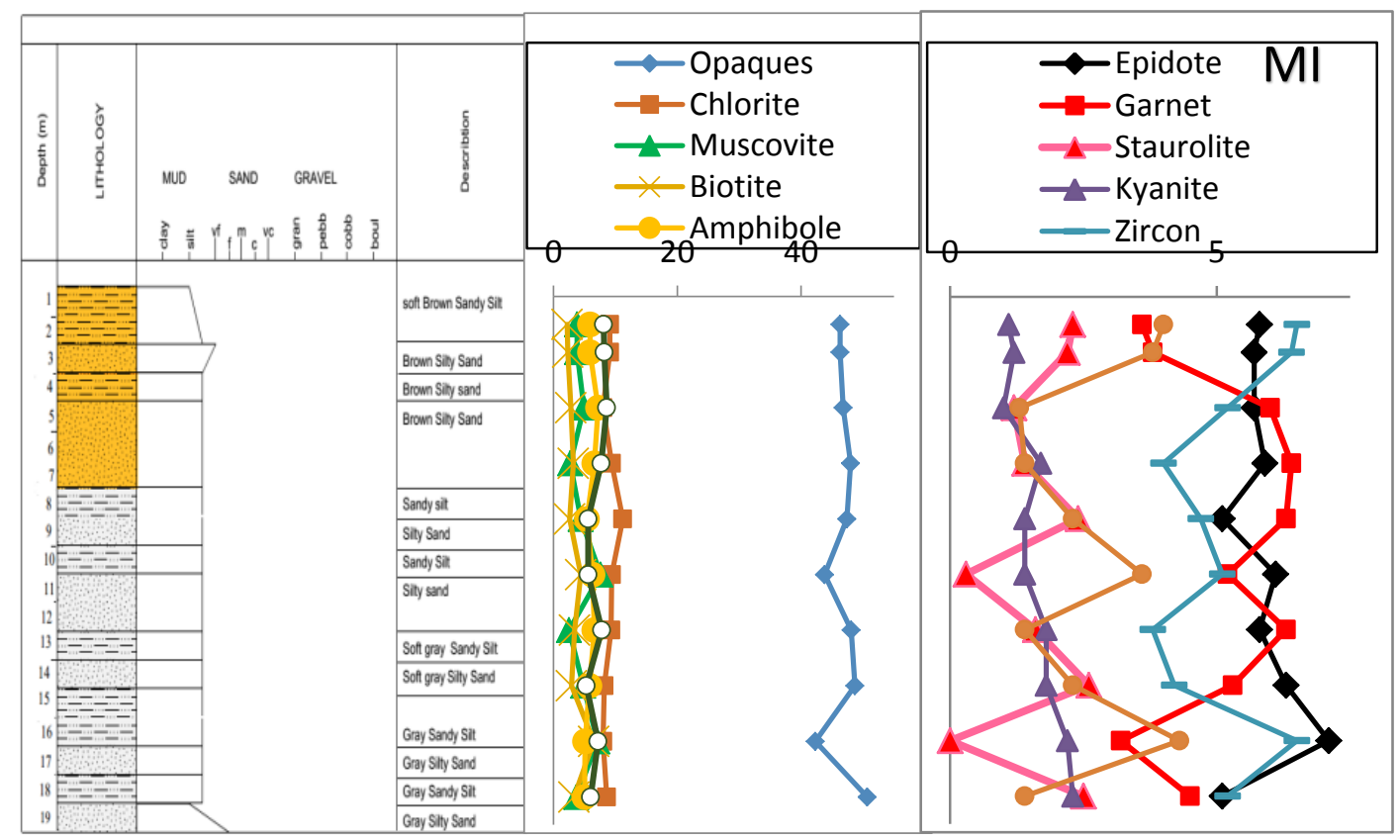

Fig. 8: Vertical variations in the percentage of the heavy minerals of Missan region

Dust-fallouts could be the main supplier of the heavy minerals were the opaque minerals recorded with a significant rate of about $46 \%$ in the three regions (Plate 1A and B); this ratio was similar to the minerals of the dunes near Thi-Qar and Missan regions (Jasim, 2017). Whereas for Tucker (1985) and Bassi et al., (1989) opaque minerals were recorded with a significant rate of about 
$46 \%$ in the three regions, tried to connect them to the river origins. Albadran et al. (1996) and Sedkhan (2009) recorded the highest percentage of these minerals which are concentrated by washing the Shatt al-Arab River sediments because the presence of these minerals in the old sediments is less than the recent one (Philip, 1968). The pyroxene and hornblende (Plate 2D, E, and F) recorded different rates but are considered to be closed across the three regions, with the average in Basrah $12.03 \%, 12 \%$ in Dhi Qar and 13\% in Missan. It is possible to have opaque, pyroxene, hornblende and chlorite that refers to the source rocks of alkali igneous rocks in the area (Folk, 1974). Whereas, the presence of Epidote, Garnet and iron oxides minerals refer to metamorphism origin (James, 1984), as well as the sedimentary origin which is observed through the rounded shape of ultra-stable minerals grains. The pyroxene and hornblende recorded different rates, but are considered to be closed across the three regions, with the average in Basrah 12.03\%, 12\% in Dhi Qar and 13\% in Missan. Epidote was recorded in Basrah at average 5.27\%, 6\% in Thi-Qar and 6 in Missan. According to Philip (1968), the percentage of this mineral is high in the old sediments compared to recent. This mineral also appears in the current rivers like the Tigris, Euphrates, and Shatt Al-Arab (Al-Ali, 1976; Albadran et al., 1996 and Sedkhan, 2009), which means that the origin of this mineral could be a river. The sources of heavy minerals in the sediments of the Euphrates River are numerous (AL-Bassam, 2000), igneous and sedimentary complexes in the areas where the river crosses in Turkey and Syria, as well as the desert valleys that rainwater contributes to the river like the Horan Valley, As well as from Dibdibba and Injana formations, which are important sources of heavy minerals in the sediments of the Euphrates River.

Mica and chlorite minerals were recorded at a good percentage of about $19 \%$ in Basrah $20 \%$ in Thi-Qar, and 17\% in Missan (Plate 2A, B, and C). Garnet was recorded in Basrah 3.62\%, 5.2\% in ThiQar and Missan about 5.06\%, in the deeper layers of the sediments of Basrah; it decreases since these beds belong to Dibdibba Formation. The chlorite ratio is predominant (Plate 1C, D, E, and F), it could be related to the Shatt Al-Arab sediments (Philip, 1968) and Missan and Thi-Qar dunes (Jasim, 2017). Ultra-stable minerals recorded at the rate of $9 \%$ in Basrah, $8 \%$ in Thi-Qar and $8 \%$ in Missan. It was observed that the minerals are well-rounded grains which could relate to the origin of the reworked sediments. Salman and Saadallah (1986), AL-Jabbry (2005) and Al-Humaidan (2018), concluded that the ultra-stable minerals in the sediments that reach to the northwest of the Arabian Gulf are from Dibdibba Formation and Al-Batin fan. For Asiedu et al. (2000 in Al-Jabbry, 2005) these minerals were supplied from the Western desert and originated from the Arabian Shield. The minerals of Kyanite and 
Staurolite (Plate 3B, C, and D) were low in the region, and the Staurolite was not recorded in the sediments of Thi-Qar, except at the $0.5 \mathrm{~m}$ depth, the source could be the Euphrates River where ALBassam and AL-Mukhtar (2008) showed that the values of Staurolite in the sediments of the Euphrates River decreases southwards, whereas its presence in 0.5 depths could be related to the aeolian sediments.

Light minerals come from multi-sources. This makes there difficult to determine the source of these sediments, as well as their high resistance for weathering processes, reflect the nature of these processes and the distances of transport, through the grain form. The results show that the carbonate and quartz minerals (Plate 3A, B, and F) are dominant in the deposits of Mesopotamia plain, due to the sedimentation environment and the multi-sources of sediments. Al-Bassam and Al-Mukhtar (2008) pointed out that most of the light minerals in the Euphrates River sediments are carbonate, quartz, and Feldspar (Plate 3C, D, and E). Figures (9, 10 and 11) show the contrast of light minerals with depths, Quartz records high ratio in the sediments and varies with depths. In the Basrah region, the quartz decreases toward the depth of $11 \mathrm{~m}$, this could belong to Hammar Formation, and then returns to increases towards the depth of $24 \mathrm{~m}$. This depth could belong to Dibdibba Formation. In the Thi-Qar, the quartz increases with depths. In Missan, it oscillates between the beds. The increase of quartz returns to its high stability and resistance to weathering. The ratio of feldspar minerals is low due to the non-stability of these minerals and transformation into clay minerals. Carbonate minerals recorded a high percentage in the sediments of the study area. In the Basrah region, carbonate increases toward the depth of $11 \mathrm{~m}$ and then returns to decreases towards the depth of $24 \mathrm{~m}$. which could refer to the transition from Hammar to Dibdibba formations. In the Thi-Qar, it is also increased with depths, while in Missan, it decreases towards the depth. This could be related to the source supplied, as well as the content of the shells, Purser and Seibold (1973) clarified that carbonate minerals are increased with fine-grained deposits. Albadran (2006) noted that the carbonate minerals in the Shatt al-Arab deposits returned to fauna shells, as well as detrital Low-Mg calcite, and authigenic carbonate. Muscovite was recorded in this study within light minerals, and this muscovite has a specific weight of less than 2.89, a significant decrease in the specific weight in the muscovite between $2.77-2.88$. Evaporites were recorded in the third-largest percentage in terms of carbonate and quartz. This can explain the hot climate of the area and the opportunity to precipitate the evaporate minerals. The study identified many types of rock fragments such as igneous, metamorphic and sedimentary rocks, and this may explain the diversity of source rocks of the study area sediments. In general, the sediments of the 
Mesopotamia Plain are immature, as the sediments of the Tigris and Euphrates Rivers and Dibdibba Formation (Philip, 1968).

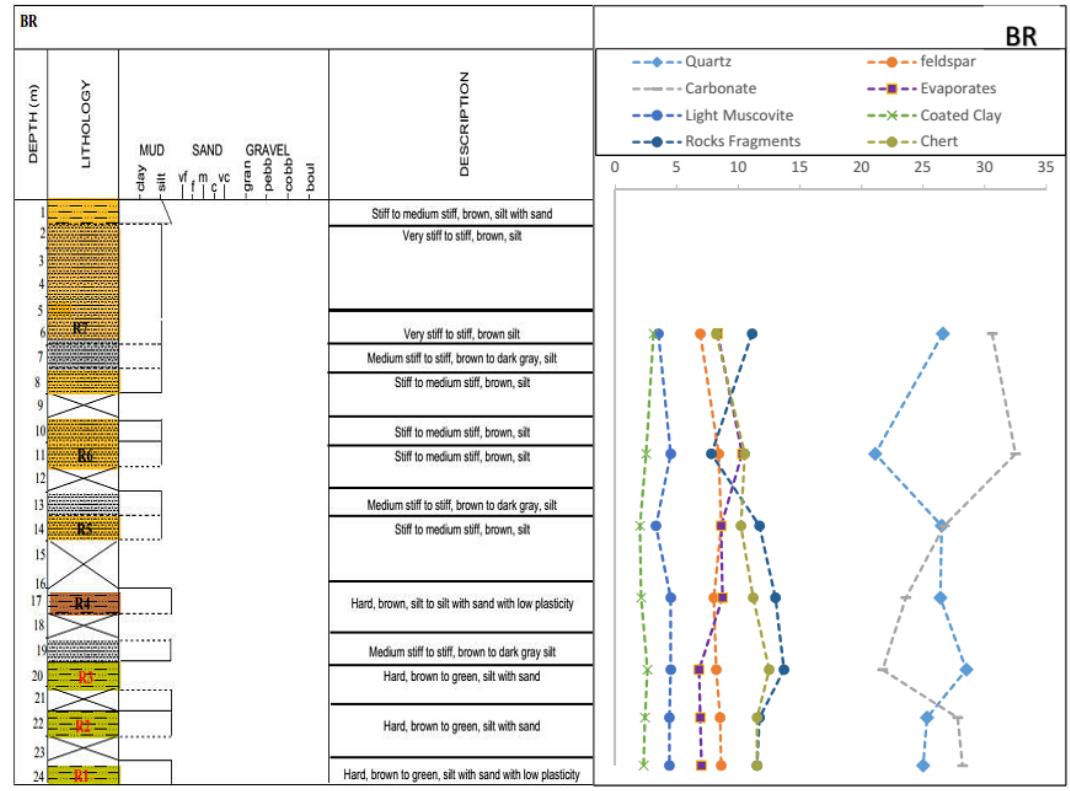

Fig. 9: Vertical variation in the light minerals percentage of Basrah region

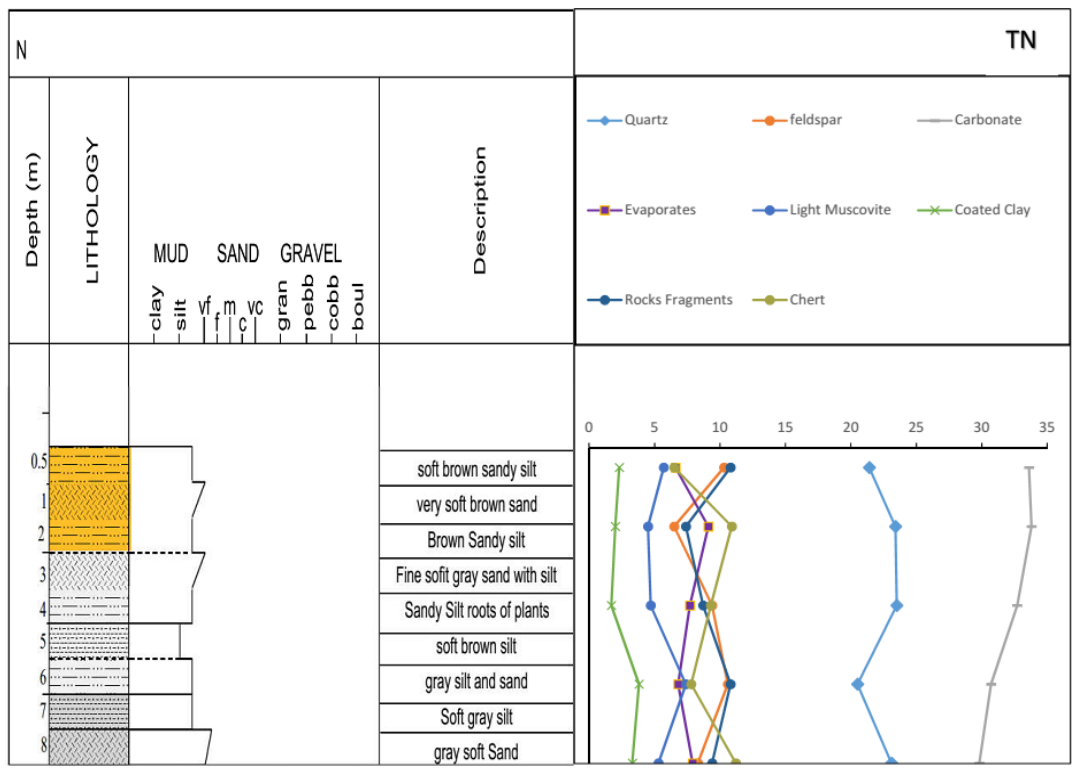

Fig. 10: Vertical variation in the light minerals percentage of Thi-Qar region 


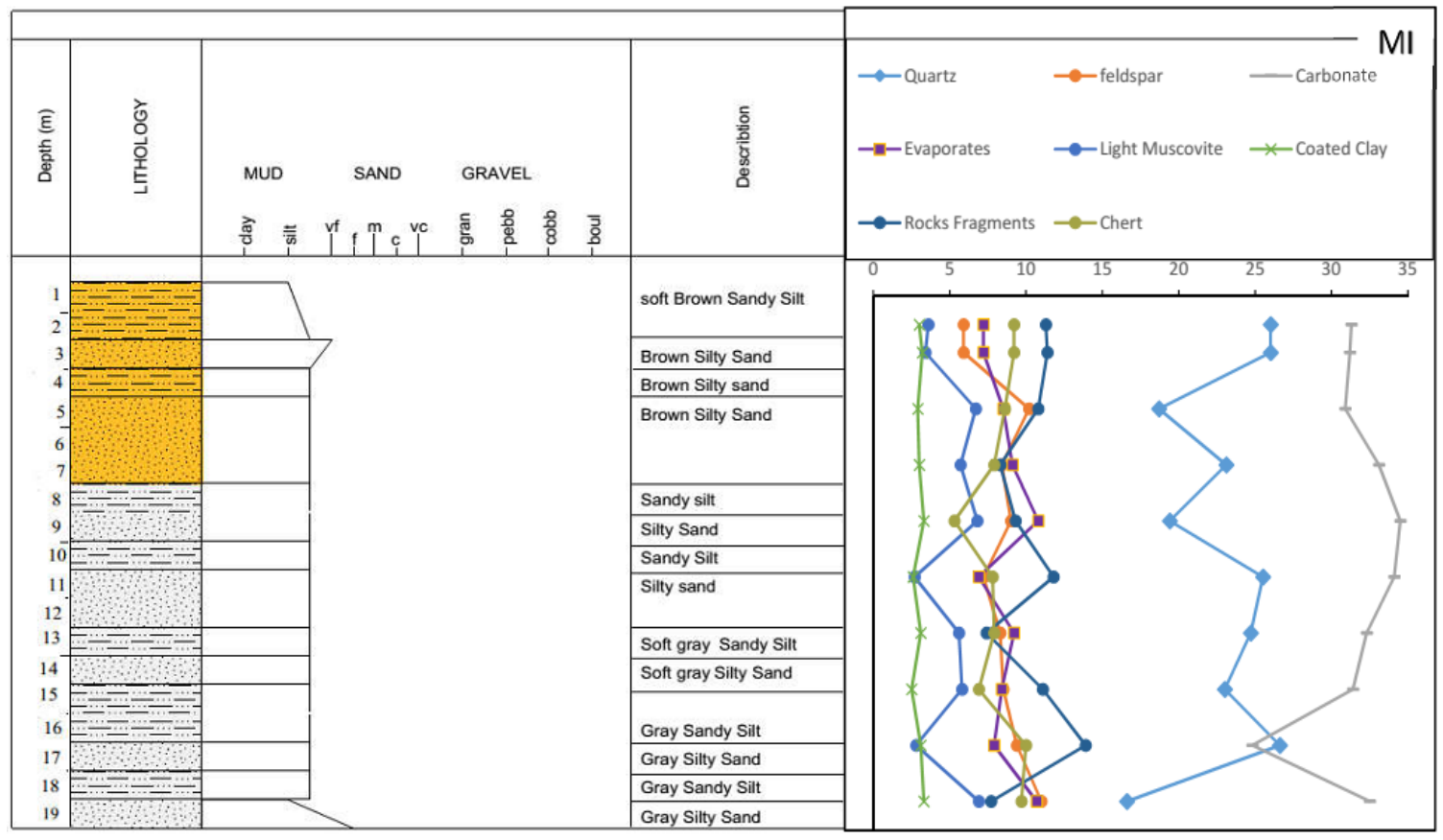

Fig. 11: Vertical variation in the light minerals percentage of Missan region

\section{CONCLUSIONS}

The sediments of the study area were classified into three types: sandy silt, silty sand and silt, and the silt fraction is the dominant size of sand and clay fraction. The sedimentation environment of the study area is shown to be of quiet energy, and the grain size decreases relatively from northern to southern. Basrah was recorded finning upward and both of Thi Qar and Missan regions recorded close grain size but different between the beds. Opaque, chlorite, muscovite, zircon, epidote, biotite, amphibole, pyroxene, and garnet, are the main heavy minerals in the study area. The diversity of heavy minerals reflects the multiple sources of sediment, represented by the igneous, metamorphism and sedimentary rocks. The mineral content shows that the sedimentary environment of the region is overlapping of fluvial, marine and aeolian. The sources of the sediments are the Tigris, Euphrates, Shatt al-Arab Rivers and the Arabian Gulf in Basrah region but in Thi-Qar and Missan the sources of their sediments are the Tigris, and Euphrates Rivers and dust- fallouts. The dominant light minerals are light muscovite and rocks fragments which related to its sedimentary origin, and presence of different minerals which include Carbonate minerals, quartz, Evaporites, Feldspar and chert, and the presence of quartz, zircon, and tourmaline refer to reworked sediments. 


\section{REFERENCES}

Abdullah, M.B., 1982. Sedimentology, Petrography, Geochemistry and Hydrochemistry of the Recent Sediments of Hor AL-Hammar in Southern Iraq. Unpublished MSc. Thesis, college of science, University of Baghdad, 192pp.

Al-Ali, A.J., 1976. Heavy mineral provinces of the recent sediments of the Euphrates - Tigris basin. Journal of geological society Iraq, 33- 46.

Al-Azzawi, T.M., 1996. Morphosedimentary and Morphotectonic of the Head of the Arabian Gulf Using Remote Sensing and Machine Analysis Techniques. Unpublished PhD. thesis, College of Science, Univ. of Baghdad, 224pp.

Albadran, A.A., 1987. Factors Influencing River Bank Stability in the Tigris and Shatt Al- Arab water ways, Iraq. Unpubl. Ph. D. Thesis, Univ. of Dendee UK, 337 pp.

Albadran, B.N., 2006. Sedimentology and mineralogy of the Al-Hammar Marsh, Southern Iraq: A review. Marsh Bulletin., 1(1): 32-39.

Albadran, B.N., Al-Beyati, F., and Abdllah, Y., 1996. Heavy minerals distribution in the lower part of the Shatt River. Marina Mesopotamica, 11(1): 17-26.

AL-Baidhany, A. H., Darmoian, S., and Albadran, B., 2002. Evaluation of Holocene sedimentary environments of the southern part of Iraq. Basrah J. Science, B, 20(1): 73-86.

AL-Bassam, K. S., 1999. Content and distribution of heavy elements in the Euphrates River sediments. National Program for the Optimal Use of Water Resources in the Euphrates Basin, AL-Muhur, 3-1. Internal Report, Ministry of Agriculture, (In Arabic).

AL-Bassam, K., 2000. The effects of geology on the Euphrates River environment. The National Program for the Optimal Use of Water Resources in the Euphrates Basin, AL-Mehur, 3-1 Internal Report, Ministry of Agriculture, (In Arabic).

AL-Bassam, K. S., and AL-Mukhtar, L. A., 2008. Heavy minerals in the sediments of Euphrates River, in Iraq. Iraqi Bulletin of Geology and Mining, 4(1): 29-41. (in Arabic).

AL- Hamad, S., Albadran, B., and Pournelle, J., 2015. Geological History of Shatt Al-Arab River, South of Iraq. International Journal of Science and Research (IJSR) ISSN (Online): 2319-7064.

Al- Hawi, N., Albadran, B., and Pournelle, J., 2017. Geoarchaeological and Morphotectonic study of Al-Hammar marsh area and surrounding. American Scientific Research Journal for Engineering, Technology, and Sciences (ASRJETS), 29(1):1-20.

Al-Humaidan, Z. A., 2018. Sedimentological, Mineralogical and Fauna Study of Marine Sediments NW of the Arabian Gulf, southern Iraq. Unpublished M.Sc. College of science, Univ. of Basrah, 121pp.

AL-Jabbry, M. H., 2005. Sedimentological, Mineralogical and Geochemical Study of Khor-Abdullah Selected Coastal Sediments N and NW Arabian Gulf. Unpublished MSc. thesis, College of Science, University of Basrah, $126 \mathrm{pp}$.

Al-Jibouri, B. S., 1997. Paleontological Evidences for Climatic and Environmental Changes During Quaternary Period in Mesopotamian Plain. South of Iraq. Unpublished. M.Sc. Thesis, Univ. of Baghdad, 80 pp. (In Arabic).

Al-Jumaily, W.A., 1994. Quaternary Ostracods in Southern Iraq. Unpubl. Ph.D. Thesis, Univ. of Baghdad, 117 pp.

AL-Malkei, A. A., Albadran, B., and Pournelle, J., 2017. A Study of sedimentology, mineralogy and biofacies of quaternary deposits of AL-Hammar and AL-Hewaza Marshes Near Qurna. International Journal of Engineering and Applied Sciences (IJEAS), 4(8).

Al-Sakini, J., 1993. New Window on the Mesopotamia History in the Light of Geological Evidences and Archaeology. Dar AL-Shaon AL-Thakafiya, ALAumah, Baghdad, 93pp.

Aqrawi, A.A., 1995. Correction of Holocene Sedimentation Rates for Mechanical Compaction: the Tigris-Euphrates Delta, Lower Mesopotamia. Marine and Petroleum Geology, 12(4): 409-416.

Barwary, A. M., 1993. The geology of Ali Al-Garbi Quadrangle. Unpublished Rep., No. 2226, Nl-38-16 (GM 28), (GEOSURV).

Bassi, M., Al-Mussawy, S. N., Ukra, K. H., and Al- Mukhtar, L. E., 1989. Mineralogy and Sources of the Recent Sediments in Khor Al- Zubair. Report: 1-73.

Boggs, J. R., 2006. Principles of Sedimentology and Stratigraphy (4 ${ }^{\text {th }}$ edition). Pearson Prentice Hall. 662 pp.

Bsho, D.Y., 2004. Hydrogeology investigations of East Missan area. The General Commission for Groundwater of Iraq. 
Buday, T., 1980. The Regional Geology of Iraq, Stratigraphy and Palaeogeography. State organization of minerals, Dar AlKutub Publishing House, Al-Mosul, Iraq, 443pp.

Buday, T., and Jassim, S.Z., 1987.The Regional Geology of Iraq Tectonism (Magmatism and Metamorphism). GEOSURV pub. Baghdad, $322 \mathrm{pp}$.

Carver, R.E., 1971. Procedures in Sedimentary Petrology. John Wiley, New York, 653 pp.

Folk, R. I., 1974. Petrology of Sedimentology Rocks. Hemphill Pub. Co, Texas, 182 pp.

Fouad, S.F., 2010.Tectonic Evolution of the Mesopotamia Foredeep in Iraq. Iraqi Bull. Geol. Min., 6(2): 41-53.

Fouad, S.F., and Sissakian, V.K., 2011. Tectonic and structure evolution of the Mesopotamia plain. Iraqi Bull. Geol. Min., special Issue, 4:33-46.

Griffiths, J.C., 1967. The Scientific Method in the Analysis of Sediments. McCraw-Hill, New York, 508 pp.

James, R., 1984. Exploration for industrial minerals in Mississippi sound and adjacent offshore territories of Mississippi and Alabama. Mississippi Mineral Resources. University of Mississippi, 11:19-83.

Jasim, H.K., 2009. Petrography and Sedimentology of Al-Muqdadiya Formation in Badra Area Eastern Iraq. Unpub. M.Sc. thesis, university of Baghdad, Iraq.

Jasim, H.K., 2017. The Sedimentology, Industrial, and Environmental Studies of the Dune Fields in Missan, Thi-Qar and Samawa Districts, Southern Iraq. Unpublished Ph.D. thesis, College of Science, University of Baghdad, 257pp.

Jassim, S.Z., and Goff, J.C., 2006. Geology of Iraq. Dolin, Prague and Moravian Museum, Brno. 341pp.

Kasper-Zubillaga, J.J., Dickinson, W.W., Carranza Edwards, A., and Hornelas-Orozco, Y., 2008. Petrography of Quartz Grains in Beach and Dune Sands of Northland, North Island, New Zealand. NZ J. Geol. Geophys., 48: 649-660.

Müller, G., 1967. Sedimentary Petrology, Part 1; Methods in Sedimentary Petrology, Translated by Hans Ulrich schmincke, Heffner, 283pp.

Pettijohn, F. J., 1975. Sedimentary Rocks. Harper and Raw Publishers, Inc., New York, 628 pp.

Philip, G., 1968. Mineralogy of recent sediment of Tigris and Euphrates and some of old detrital deposits. Journal of sedimentary petrology, 38(1): 35-44.

Pournelle, J., AL-Sudani, K. J., and Albadran, B., 2019. Geoarchaeological history of the oldest site Hareer's tells, in Basrah City, Southern Iraq. Basrah J. of science, 37(1): 44- 61.

Purser, B.H., and Seibold, E., 1973. The principal environmental factors influencing Holocene sedimentation and diagenesis in the Persian Gulf. In Purser, Bruce H. (Ed.), The Persian Gulf Holocene Carbonate Sedimentation and Diagenesis in a Shallow Epicontinental Sea. Springer -Velag, Germany, 1-10.

Salman, H., and Saadallah, A., 1986. Dust fallout in central and southern part of Iraq. Jour. Water Resources, 5(1): 599621.

Sedkhan, M. T., 2009. Sedimentary, Hydrographic and Mineralogical Study for the Confluence Area of Karun and Shatt alArab Rivers and its Surrounded Areas. M.Sc. thesis, College of Science, Basrah University, 79 pp.

Tucker, M. E., 1985. Sedimentary Petrology. An introduction, $4^{\text {th }}$ editions; Black Well Scientific Publishing, 252 pp.

Yacoub, S. Y., 2011a. Geomorphology of mesopotamia plain. Iraqi Bull. Geol. Min., Special Issue, 4:7-32.

Yacoub, S.Y., 2011b. Stratigraphy of mesopotamia plain. Iraqi Bull. geol. min., special Issue, 4: 47-82.

Yacoub, S.Y., Purser, B.H., Al-Hassni, N.H., Al-Azawi, M., Orzag-Sperber, F., Hassan, K.M., Plaziat, J.C. and Younis, W.R., 1981. Preliminary study of the Quaternary sediments of SE Iraq. Joint research project by the Geological Survey of Iraq and University of Paris XI, Orsay. GEOSURV, int. rep. no. 1078. 

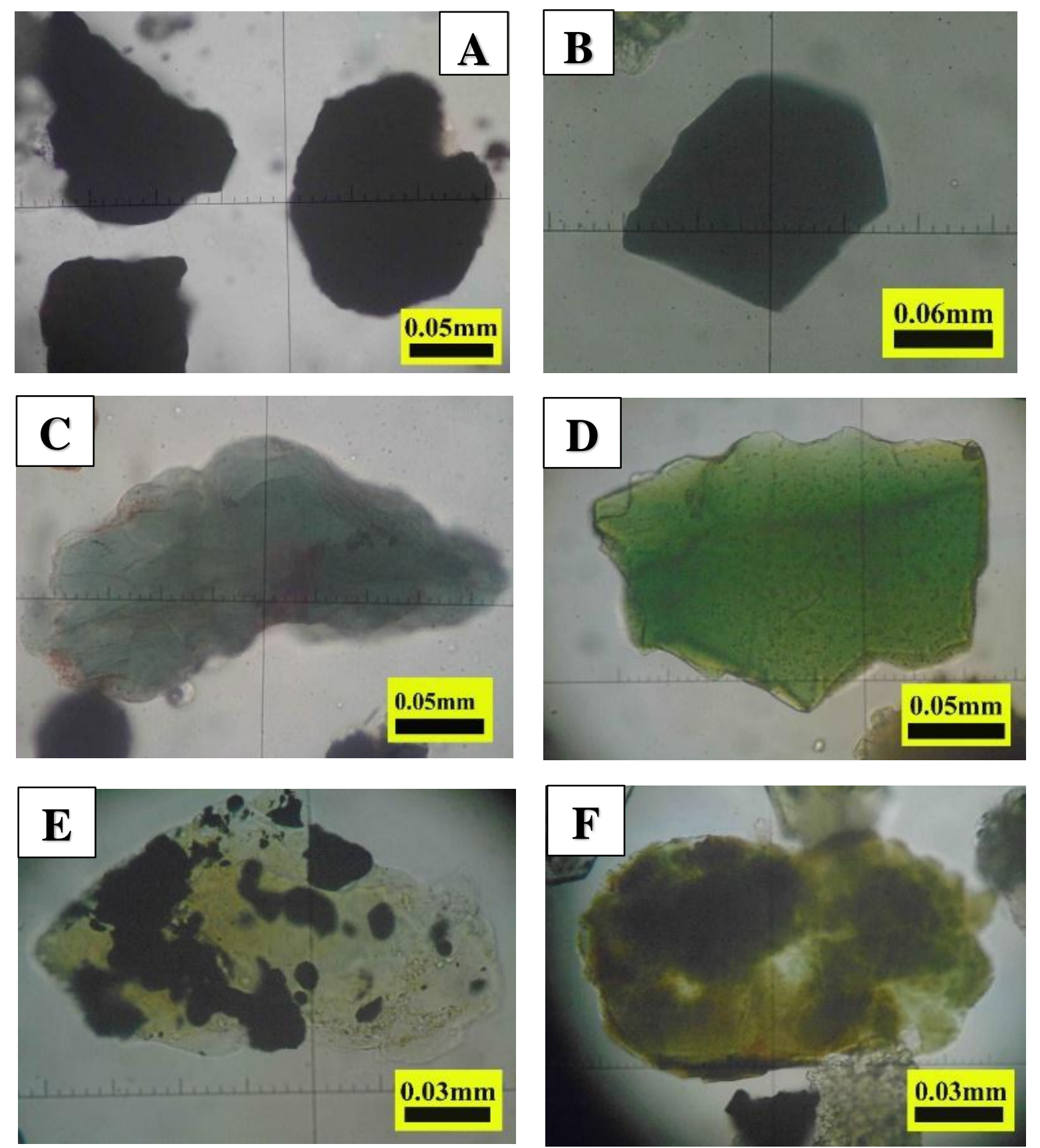

Plate 1: Heavy minerals under polarizing microscopic

(A) \& (B) Opaque grain (Iron Oxide), sample number MI6, PPL

(C) Fresh green chlorite, sample number MI19, PPL

(D) Fresh green chlorite, sample number MI2, PPL

(E) Flaky form, brown chlorite with spots of iron oxides, sample number TN7, PPL

(F) Altered corroded chlorite, sample number TN7, PPL 

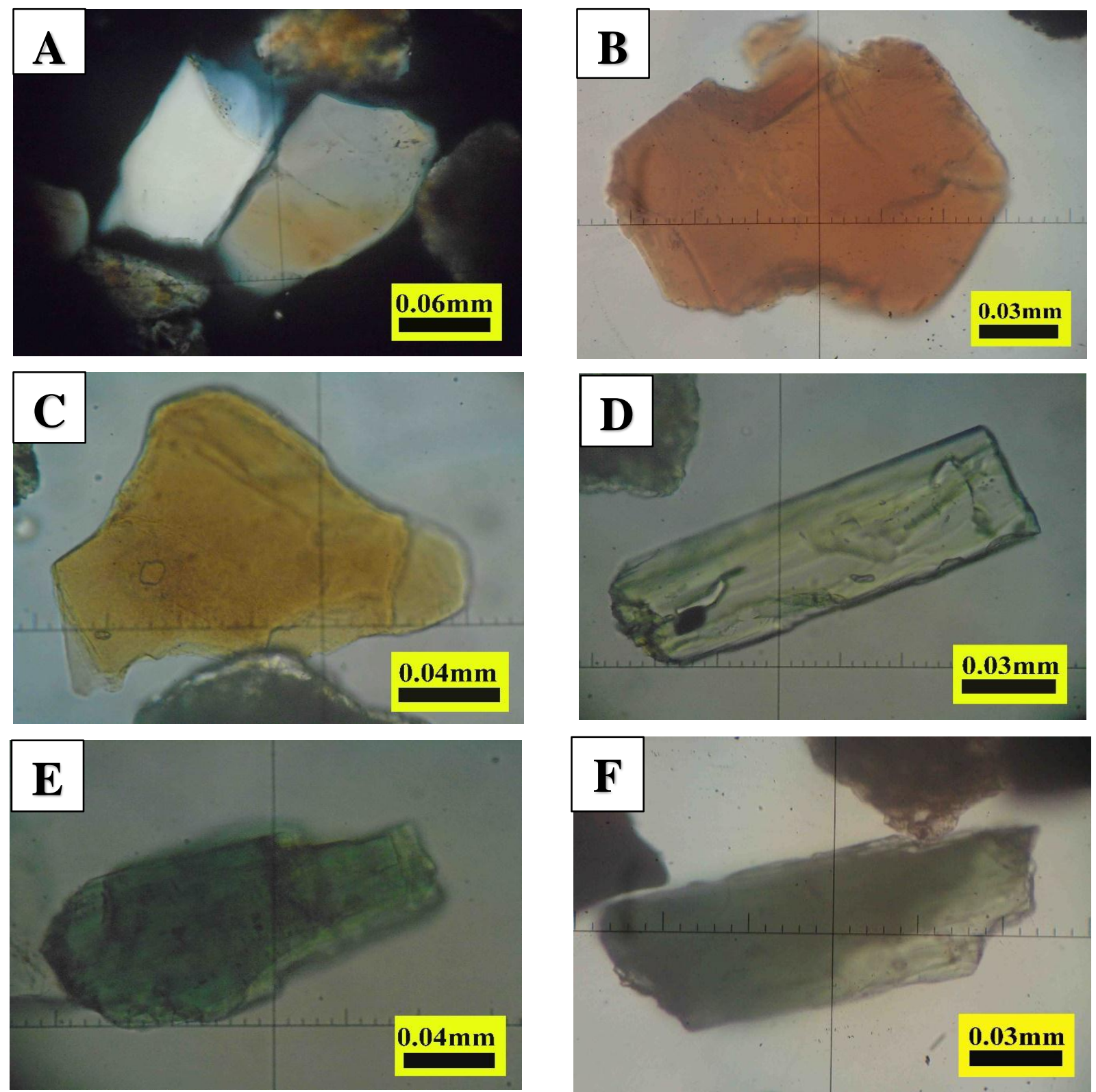

Plate 2: Heavy minerals under polarizing microscopic

(A) Flaky form, fresh muscovite mica, sample number MI6, XPL

(B) Flaky form, brown color, pleochroic biotite, sample number MI10, PPL

(C) Flaky form, light brown color, pleochroic biotite, sample number MI2, PPL

(D) Orthopyroxene (Enstatite), sample number BR1, PPL

(E) green color, subhedral prismatic clinopyroxene, sample number MI6, PPL

(F) green color, subhedral prismatic clinopyroxene, sample number TN9, PPL 

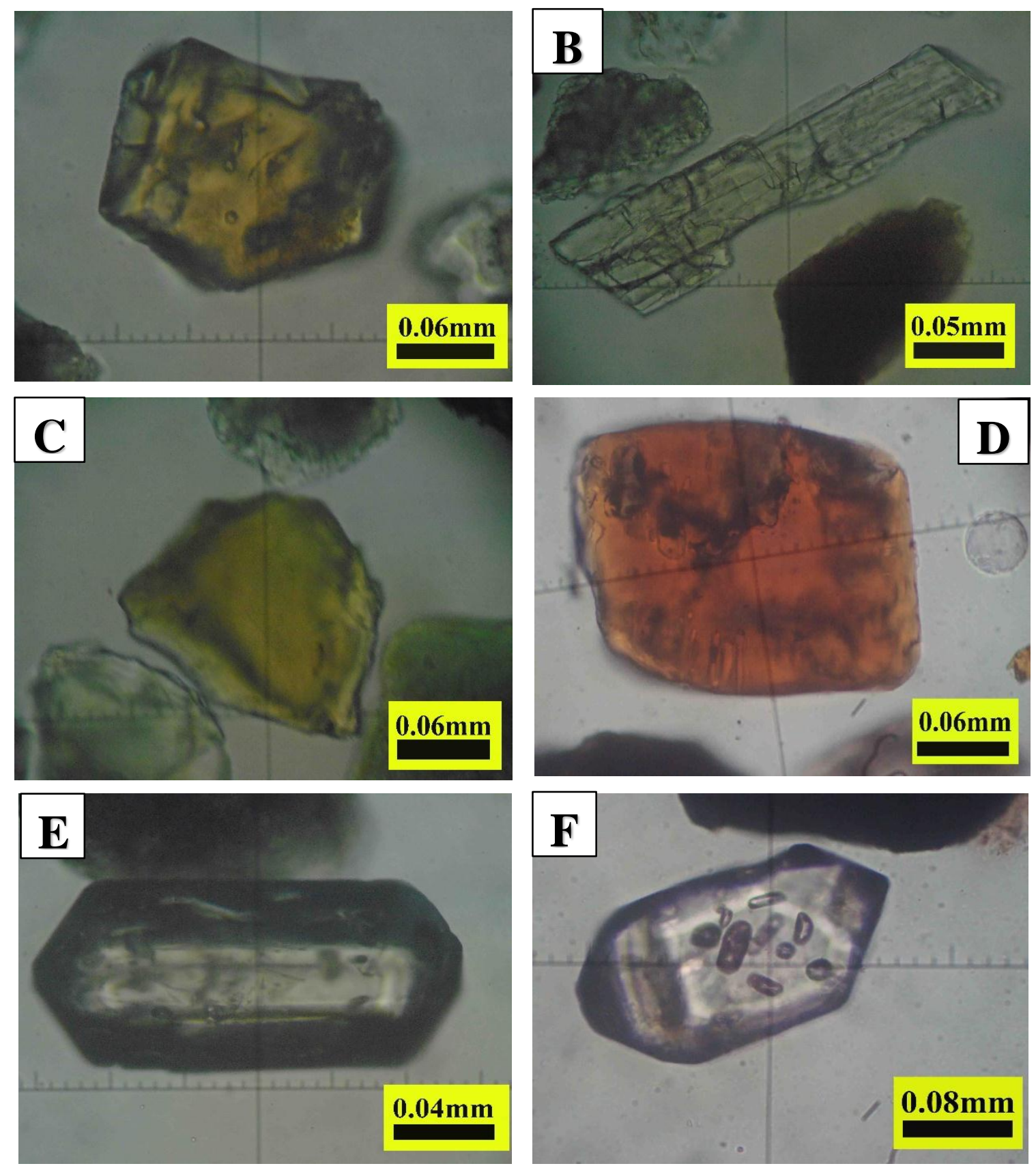

Plate 3: Heavy minerals under polarizing microscopic

A: High Relief, Light brown garnet, sample number MI2, PPL

B: High relief, prismatic, colorless kyanite, sample number TN7, PPL

C: Yellowish color, staurolite, sample number TN7, PPL

D: Yellowish color, staurolite, sample number BR3, PPL

E: High relief, euhedral, prismatic, colorless zircon with black shades, TN7, PPL

F: Euhedral, prismatic, colorless zircon with blue shades, sample number BR4, PPL 

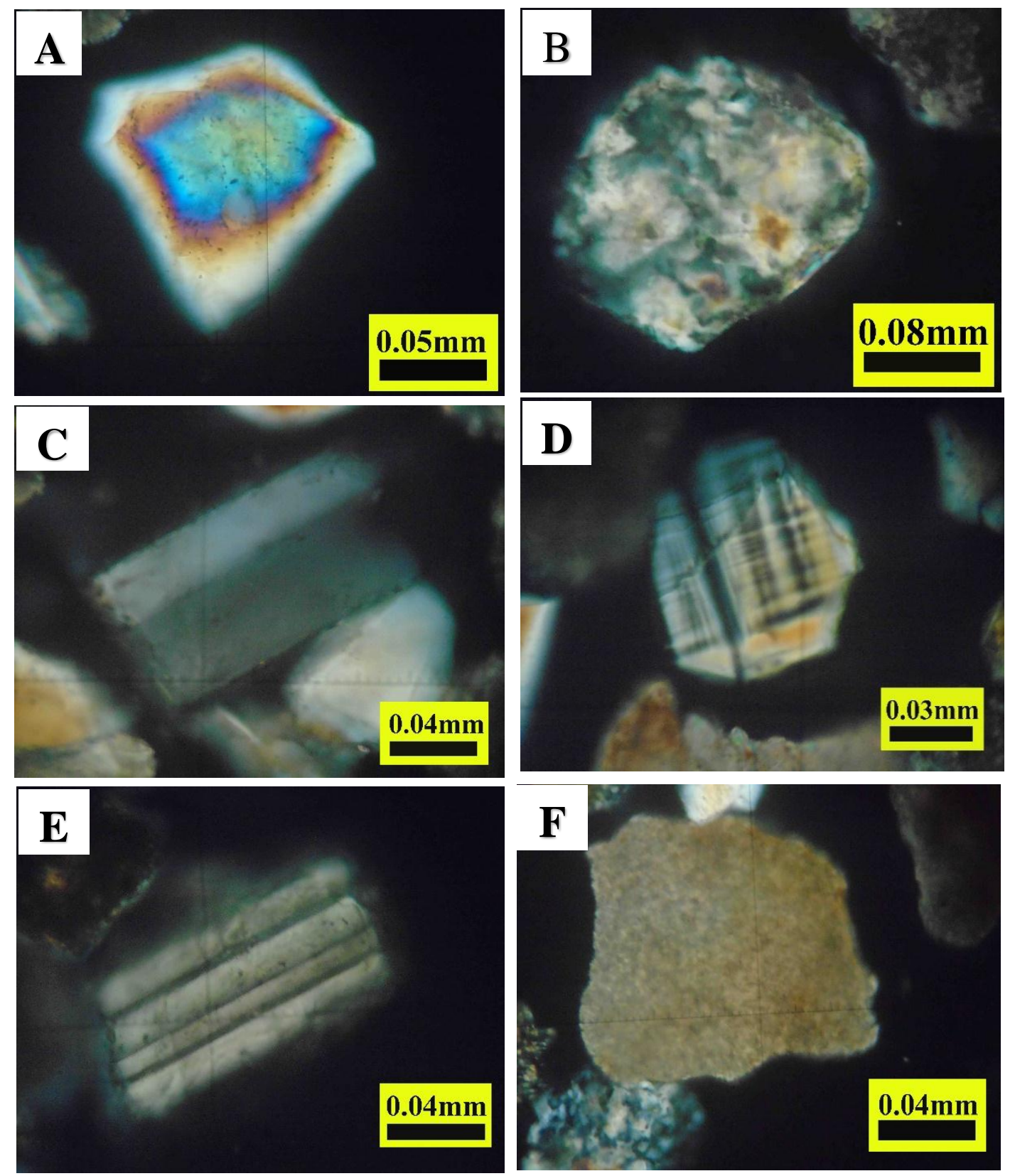

Plate (4): Light minerals under polarizing microscopic

(A )Monocrystalline quartz, sample number TN5, XPL

(B) Polycrystalline quartz, sample number TN3, XPL

(C) Euhedral alkali feldspar (Orthoclase), sample number TN7, XPL

(D) Alkali feldspar (Microcline), sample number TN1L, XPL

(E) Subhedral, plagioclase feldspar, Sample number BR2, XPL

(F) Carbonate minerals (Limestone), sample number TN5, XPL 